\title{
FAKTOR-FAKTOR YANG MEMPENGARUHI KEPATUHAN WAJIB PAJAK FINAL PP NOMOR 46 TAHUN 2013 PADA UMKM DI KABUPATEN REMBANG
}

\begin{abstract}
Pajak berperan aktif dalam rangka meningkatkan pembangunan nasional melalui pemungutan yang dilakukan terhadap wajib pajak orang pribadi atau wajib pajak badan. UMKM merupakan salah satu wajib pajak yang memberikan kontribusi signifikan terhadap penerimaan negara jika dari semuanya patuh terhadap pembayaran pajak, karena jumlah UMKM di Indonesia sangat besar. PP Nomor 46 tahun 2013 mengatur tentang punggutan pajak UMKM yang peredaran bruto atau omset dalam satu tahun belum mencapai 4,8 Milyar rupiah. Namun ada beberapa faktor yang mempengaruhi tingkat kepatuhan pajak diantaranya adalah kurangnya pengetahuan tentang perpajakan, persepsi keadilan pajak serta kebutuhan permodalan dan kredit memicu wajib pajak taat akan pembayaran pajak sebagai salah satu persyaratan administratif Lembaga Perbankan.

Penelitian ini bertujuan untuk menguji pengaruh pengetahuan perpajakan, persepsi keadilan pajak, serta kebutuhan permodalan dan kredit terhadap kepatuhan pajak final PP Nomor 46 Tahun 2013 pada UMKM di Kabupaten Rembang. Berdasarkan uji hipotesis yang dilakukan variabel pengetahuan pajak berpengaruh signifikan terhadap kepatuhan wajib pajak final PP Nomor 46 Tahun 2013. Sedangkan variabel persepsi keadilan pajak dan kebutuhan permodalan dan kredit tidak perpengaruh terhadap kepatuhan wajib pajak UMKM dalam membayar pajak.
\end{abstract}

Keyword: Kepatuhan Pajak, PP Nomor 46 Tahun 2013, Pengetahuan Pajak, Persepsi Keadilan Pajak, Kebutuhan Permodalan dan Kredit UMKM

\section{PENDAHULUAN}

Pajak merupakan salah satu sumber penerimaan negara yang memberikan kontribusi besar dalam upaya peningkatan penerimaan negara. Pajak berperan aktif dalam rangka meningkatkan pembangunan nasional melalui pemungutan yang dilakukan terhadap wajib pajak orang pribadi atau wajib pajak badan (Rosella dan Kurnia, 2015). Hal ini terlihat dalam Anggaran Penerimaan dan Belanja Negara (APBN) dimana penerimaan pajak menjadi salah satu penerimaan terbesar dari dalam negeri. Besarnya pengeluaran pemerintah dalam rangka pembiayaan negara menuntut peningkatan penerimaannya pula yang salah satunya dari pajak.

Pajak merupakan iuran kepada negara yang sifatnya dapat dipaksakan yang terutang oleh yang wajib membayarkannya menurut peraturan perundang-undangan dengan tidak mendapat kontrapretasi kembali, yang langsung ditunjuk dan gunanya untuk membiayai pengeluaran- pengeluaran umum berhubungan dengan tugas negara untuk menyelenggarakan pemerintahan (Waluyo dalam Andriyani yang telah diterjemahkan oleh Brotodiharjo, 1992:2).

Salah satu penyebab belum optimalnya penerimaan pajak di Indonesia adalah rendahnya tingkat 
kepatuhan wajib pajak. Seperti yang dikemukakan Menteri Keuangan Agus Martowardjo mengungkapkan tingkat kepatuhan masyarakat Indonesia sebagai wajib pajak masih rendah (www.kompas.com, 20 Oktober 2011). Data tersebut diperkuat dengan fakta pada tahun 2015 hanya 9,92 juta wajib pajak yang menyerahkan SPT dari 27 juta wajib pajak yang terdaftar di Kantor Pelayanan Pajak (KPP) (www.liputan6.com, 13 April 2015). Dengan demikian rasio SPT terhadap wajib pajak yang terdaftar di KPP hanya 36,75 persen atau dengan tingkat kepatuhan pajak yang belum memadai. Lebih lanjut wajib pajak badan yang menyerahkan SPT pada tahun 2015 mencapai 164.359 wajib pajak, jumlah tersebut naik sebesar 33,13 persen dari tahun sebelumnya yang jumlahnya hanya sekitar 123.459 wajib pajak.

Peningkatan kesadaran dan kepatuhan terhadap kewajiban perpajakan, wajib pajak badan maupun orang pribadi juga berharap agar upaya pemerintah dalam mengoptimalkan potensi perpajakan berlandaskan atas asas keadilan sosial. Dalam rangka peningkatan kesadaran dan kepatuhan wajib pajak membayar kewajiban pajaknya pada tahun 2013 pemerintah mengeluarkan kebijakan perpajakan untuk UMKM sebesar 1 persen dari omset perbulan yang diatur dalam PP Nomor 46 tahun 2013.

Mengingat Usaha Mikro Kecil dan Menengah (UMKM) mempunyai peran penting dan strategis dalam pembangunan ekonomi nasional. Selain berperan dalam pertumbuhan ekonomi dan penyerapan tenaga kerja, UMKM juga berperan dalam mendistribusikan hasil-hasil pembangunan. Berdasarkan data Kementrian Koprasi dan UKM pada tahun 2014 bahwa kontribusi UMKM terhadap Produk Domestik Bruto (PDB) sebesar 57-60 \% dan tingkat penyerapan tenaga kerja sebesar 97\% dari seluruh tenaga kerja nasional. Persentase tersebut diharapkan akan terus meningkat pada tahun-tahun mendatang dikarenakan pertumbuhan ekonomi Indonesia yang semakin membaik. Data global menunjukkan kontribusi yang signifikan dari UMKM yaitu rata - rata sebesar 95\% dari kondisi ekonomi sebagian besar negara bergantung pada UMKM.

Berkaitan dengan semakin meningkatnya jumlah UMKM yang ada di Indonesia, pemerintah mengharapkan adanya kesadaran pembayaran pajak final PP Nomor 46 Tahun 2013 yang diberlakukan untuk UMKM dengan tingkat peredaran usaha kurang dari 4,8 Milyar dalam satu tahun yang perhitungan pajaknya adalah 1 persen dari peredaran bruto. Pada umumnya kendala ketaatan pembayaran pajak final PP Nomor 46 Tahun 2013 adalah kurangnya pengetahuan pelaku UMKM tentang peraturan perpajakan. Hal ini dikarenakan keterbatasan sumber daya dan rendahnya pendidikan pelaku UMKM tentang perpajakan.

Adapula pelaku UMKM yang sadar akan kewajiban membayar pajak untuk kegiatan usahanya, namun kesadaran dalam pembayaran pajak tersebut hanya dilakukan sesekali saja guna untuk persyaratan pengajuan modal kepada Lembaga Keuangan, baik Bank maupun koprasi. Pada umumnya Lembaga Keuangan akan memberikan pinjaman modal kepada para pelaku UMKM yang berskala besar dengan persyaratan memiliki NPWP. Pelaku UMKM yang memiliki NPWP secara otomatis wajib membayar pajak dan melaporkan SPT masa atau SPT tahunan.

Sekilas Nampak memudahkan, namun dalam PP Nomor 46 tahun 2013 ini terdapat ketidakadilan karena margin UMKM berbeda-beda. Terdapat pro dan kontra selama pemberlakuan peraturan ini. Sebagai contoh bagi UMKM yang bergerak dibidang jasa yang memiliki profit margin besar, mereka akan diuntungkan dengan adanya peraturan tersebut karena hanya dihitung 1 persen dariomset, bukan lagi menghitung pajakberdasarkan

Jurnal Akuntansi Indonesia

Vol. 8 No. 1 Januari 2019 
laba yang diterima, berkebalikan dengan UMKM yang memiliki profit margin kecil merasa keberatan dengan pemberlakuan peraturan tersebut karena harus menyetorkan pajak lebih besar dibandingkan perhitungana pajak berdasarkan laba bersih.

Rosella dan Kurnia, (2015) yang telah melakukan penelitian tentang Pengaruh Persepsi atas PP nomor 46 Tahun 2013 Terhadap Kepatuhan wajib pajak, menunjukan bahwa persepsi keadilan pajak dan persepsi kemudahan pajak PP Nomor 46 Tahun 2013 berpengaruh positif signifikan terhadap kepatuhan pajak.

Penelitian berbasis studi kasus pada UMKM yang dilakukan Endrianto (2015) tentang Prinsip Keadilan dalam Pajak Atas UMKM memberikan hasil bahwa perhitungan pajak PP Nomor 46 Tahun 2013 cukup memudahkan bagi pelaku UMKM dalam melaksanakan kewajiban pajaknya karena pengusaha UMKM sebagian besar masih melakukan pembukuan secara tradisional terhadap transaksi usaha mereka. Pengenaan PPH 1 persen ini juga dapat mendidik pelaku UMKM untuk patuh dalam kewajiban perpajakan dan memberi kemudahan kepada UMKM dalam melakukan perhitungan, penyetoran, dan pelaporan pajak penghasilan yang terutang. Melihat pentingnya pajak sebagai salah satu penerimaan negara terbesar, maka pemerintah mengeluarkan kebijakan PP Nomor 46Tahun 2013 untuk UMKM dengan harapan UMKM mampu menyumbang pajak untuk penerimaan negara. Namun, terdapat kendala yang dihadapi UMKM dalam rangka memenuhi kewajiban pajaknya diantaranya adalah kurangnya pengetahuan perpajakan, persepsi ketidakadilan pajak serta kebutuhan permodalan dan kredit perbankan.

Pajak masih menjadi salah satu penerimaan kas negara yang berkontribusi besar terhadap pembangunan nasional. Salah satu pajak yang dipungut oleh pemerintah pusat yang pemungutannya dilakukan oleh kantor pelayanan pajak, yaitu pajak penghasilan (PPh). Pajak penghasilan (PPh) merupakan suatu perlakuan perpajakan yang dikenakan kepada wajib pajak atas segala pendapatan yang diterima negara dalam satu periode pajak. Pendapatan yang dimaksud berupa gaji, upah, tunjangan, bunga dan pendapatan berasal dari laba usaha (Nurazizah, 2011). UMKM merupakan usaha yang berskala kecil dan menengah yang dikenakan pajak penghasilan dengan dasar pengenaan pajak sebesar 1 persen dari omset atau peredaran bruto dengan skala peredaran bruto dalam satu tahun kurang dari 4,8 Milyar diatur dalam PP Nomor 46 Tahun 2013. Namun belum semua wajib pajak UMKM yang sadar akan kewajiban pajaknya. Berdasarkan uraian diatas maka tujuan penelitian ini adalah menganalisis bagaimana pengaruh pengetahuan pajak, persepsi keadilan pajak serta kebutuhan permodalan dan kredit terhadap kepatuhan wajib pajak final PP Nomor 46 Tahun 2013 pada Usaha Mikro Kecil Menengah di Kabupaten Rembang.

\section{TINJAUAN PUSTAKA DAN PENGEMBANGAN HIPOTESIS}

\section{Teori Kebijakan Publik}

Menurut Chandler dan Plano (1988) kebijakan publik yaitu pemanfaatan yang strategis terhadap sumberdaya yang ada untuk memecahkan masalah-masalah publik atau pemerintah. Kebijakan publik merupakan suatu bentuk intervensi yang dilakukan secara terus menerus oleh pemerintah demi kepentingan kelompok yang kurang beruntung dalam masyarakat agar mereka dapat hidup, dan ikut dalam pembangunan 
secara luas. Dalam hal ini pemerintah mendayagunakan berbagai instrumen yang dimiliki untuk mengatasi persoalan publik.

\section{Kepatuhan Pajak Final PP Nomor 46 Tahun 2013}

PP Nomor 46 Tahun 2013 memiliki 2 (dua) landasan hukum, yaitu : Pasal 4 ayat (2) huruf e UU PPh dan Pasal 17 ayat (7) UU PPh. Adapun maksud dari diterbitkannya PP Nomor 46 Tahun 2013, yaitu memberikan kemudahan dan penyederhanaan aturan perpajakan, mengedukasi masyarakat untuk tertib administrasi, mengedukasi masyarakat untuk transparansi, dan memberikan kesempatan masyarakat untuk berkontribusi dalam penyelenggaraan Negara.

Objek pajak berdasarkan PP Nomor 46 Tahun 2013 adalah penghasilan dari usaha yang diterima atau diperoleh Wajib Pajak dengan peredaran bruto (omset) yang tidak melebihi Rp4.800.000.000,00 dalam satu tahun pajak. Apabila peredaran bruto tahun sebelumnya tidak melebihi Rp 4.800.000.000,00, maka tahun berikutnya dikenai pajak yang bersifat final sesuai dengan ketentuan dalam Peraturan Pemerintah ini. Peredaran bruto (omset) merupakan peredaran bruto dari usaha, termasuk dari usaha cabang, selain peredaran bruto dari usaha yang atas penghasilannya telah dikenai Pajak Penghasilan yang bersifat final berdasarkan ketentuan Peraturan Perundang-undangan di bidang perpajakan.

Subjek Pajak dari PP Nomor 46 Tahun 2013 adalah Wajib Pajak Orang pribadi dan Wajib Pajak Badan yang peredaran usaha dalam satu tahun tidak melebihi 4,8 Milyar Rupiah. Tarif Pajak Penghasilan terutang untuk PP 46 Tahun 2013 sebesar satu persen dari jumlah peredaran bruto setiap bulan. Wajib Pajak dapat melaporkannya melalui kantor pos atau bank yang ditunjuk oleh Menteri Keuangan dengan menggunakan Surat Setoran Pajak (SSP) atau sarana administrasi lain yang dipersamakan dengan SSP paling lama tanggal lima belas pada bulan berikutnya setelah masa pajak berakhir. Yang dimaksudkan kepatuhan pajak final PP Nomor 46 Tahun 2013 adalah Wajib Pajak Orang Pribadi atau Badan melakukan perhitungan, pembayaran Pajak Penghasilan dan menyampaikan Surat Pemberitahuan (SPT) masa pajak Penghasilan paling lama dua puluh hari setelah Masa Pajak berakhir. Wajib Pajak yang telah melakukan penyetoran Pajak Penghasilan, dianggap telah menyampaikan Surat Pemberitahuan Masa Pajak Penghasilan sesuai dengan tanggal validasi Nomor Transaksi Penerimaan Negara (NTPN) yang tercantum pada SSP (Haryati dan Noviari, 2016).

Menurut Noman D. Nowak (Zain, 2004) kepatuhan wajib pajak merupakan suatu iklim kepatuhan dan kesadaran pemenuhan kewajiban perpajakan, tercermin dalam situasi dimana wajib pajak paham atau berusaha untuk memahami semua ketentuan peraturan perundang-undangan perpajakan, mengisi formulir pajak yang lengkap dan jelas, menghitung jumlah pajak yang terutang dengan benar dan membayar pajak yang terutang tepat pada waktunya.

Indikator kepatuhan pajak itu sendiri menurut Chaizi Nasucha yang dikutip oleh Siti Kurnia (2010:139), yaitu :

a) Menyampaikan SPT Tahunan PPh tepat waktu

b) Kepatuhan wajib pajak dalam mendaftarkan diri

c) Kepatuan untuk menyetorkan kembali surat pemberitahuan

Jurnal Akuntansi Indonesia

Vol. 8 No. 1 Januari 2019 
d) Kepatuhan dalam perhitungan dan pembayaran pajak terutang

e) Kepatuhan dalam pembayaran dan tunggakan

\section{Pengetahuan Perpajakan}

Pajak dari perspektif ekonomi dipahami sebagai beralihnya sumber daya dari sektor privat kepada sektor publik. Pemahaman ini memberikan gambaran bahwa adanya pajak menyebabkan dua situasi menjadi berubah. Pertama, berkurangnya kemampuan individu dalam menguasai sumber daya untuk kepentingan penguasaan barang dan jasa. Kedua, bertambahnya kemampuan keuangan negara dalam penyediaan barang dan jasa publik yang merupakan kebutuhan masyarakat (Aditra dkk, 2016). Pengetahuan perpajakan yang dimaksud dalam penelitian ini adalah sejauh mana wajib pajak Orang Pribadi atau Badan mengetahui kewajiban pembayaran pajaknya. Dalam hal ini sejauh mana pengetahuan wajib pajak mengetahui Peraturan Pemerintah Nomor 46 Tahun 2013 tentang pajak yang diberlakukan untuk UMKM dengan omset atau pendapatan bruto tidak melebihi 4,8 Milyar Rupiah.

Andriyani (2000:25) menyatakan pengetahuan pajak adalah pengetahuan mengenai konsep umum dibidang perpajakan yang berlaku di Indonesia mulai dari subjek pajak, objek pajak, tarif pajak, perhitungan pajak terutang, pencatatan pajak terutang sampai dengan cara pengisian pelaporan pajak. Dari pengertian diatas dapat disimpulkan bahwa pengetahuan pajak adalah informasi pajak yang dapat digunakan Wajib Pajak sebagai dasar untuk bertindak, mengambil keputusan dan untuk menempuh arah atau strategi tertentu sehubungan dengan pelaksanaan hak dan kewaiban dibidang perpajakan. Indikator dari pengetahuan pajak menurut Nurhayati (2008) dalam Endrianto (2015) yaitu:

a) Pengetuahuan mengenai batas waktu pembayaran dan pelaporan

b) Pengetahuan mengenai ketentuan umum dan tata cara perpajakan

c) Pengetahuan mengenai sistem perpajakan

\section{Persepsi Keadilan Pajak}

Persepsi keadilan pajak PP Nomor 46 Tahun 2013 dalam penelitian ini didefinisikan sebagai suatu proses seseorang mengorganisasi, menginterpretasi, mengalami dan mengolah informasi dari luar mengenai keserhanaan, kemudahan, keadilan, dan penghapusan sanksi administrasi yang telah ditetapkan dalam PP Nomor 46 Tahun 2013 (Bashori, 2014). Menurut Anggraeni mendefinisikan keadilan pajak sebagai suatu penilaian dari wajib pajak yang dikenai Pajak Penghasilan sesuai ketentuan dalam PP Nomor 46 Tahun 2013 terkait unsur-unsur pajak yang adil dengan ditetapkan dan dilaksanakannya PP Nomor 46 Tahun 2013. Apakah unsur-unsur dalam PP Nomor 46 Tahun 2013 memberikan rasa keadilan atau sebaliknya.

Andriyani (2000:25) menyatakan pengetahuan pajak adalah pengetahuan mengenai konsep umum dibidang perpajakan yang berlaku di Indonesia mulai dari subjek pajak, objek pajak, tarif pajak, perhitungan pajak terutang, pencatatan pajak terutang sampai dengan cara pengisian pelaporan pajak.

Dari pengertian diatas dapat disimpulkan bahwa pengetahuan pajak adalah informasi pajak yang dapat digunakan Wajib Pajak sebagai dasar untuk bertindak, mengambil keputusan dan untuk menempuh arah atau 
strategi tertentu sehubungan dengan pelaksanaan hak dan kewaiban dibidang perpajakan. Indikator dari pengetahuan pajak menurut Nurhayati (2008) dalam Endrianto (2015) yaitu:
a) Pengetuahuan mengenai batas waktu pembayaran dan pelaporan
b) Pengetahuan mengenai ketentuan umum dan tata cara perpajakan
c) Pengetahuan mengenai sistem perpajakan

\section{Kebutuhan Permodalan dan Kredit}

Kebutuhan modal sangat berpengaruh terhadap perkembangan usaha. Kebutuhan permodalan menjadi salah satu masalah mendasar UMKM dalam menjalankan usahannya, dengan terbatasnya akses terhadap sumber-sumber pembiayaan dari Lembaga Keuangan Perbankan (Wijono, 2005 dalam Maratis, 2014). Keterbatasan modal tersebut akan mempengaruhi kinerja UMKM yaitu menurunnya jumlah produksi dan penjualan maka menyebabkan berkurangnya pula jumlah penghasilan atau pendapatan yang diperoleh. Bagi UMKM kredit dirasa penting untuk memenuhi kebutuhan modal kerja yang diperlukan guna meningkatkan kinerja usahannya. Namun, pengajuan kredit yang relatif besar mensyaratkan adanya NPWP sebagai salah satu prosedur pengajuan kredit. Maka pemilik UMKM diharuskan mendaftarkan diri sebagai wajib pajak dengan mendaftar dikantor pelayanan pajak untuk mendapat Nomor Pokok Wajib Pajak (NPWP). Dengan demikian wajib pajak yang berNPWP wajib menyetorkan pajak penghasilan sesuai dengan ketentuan pajak PP Nomor 46 Tahun 2013.

\section{Penelitian Terdahulu}

Firdaus (2014) melakukan penelitin dengan judul Pengaruh Pengetahuan Pajak, Kemudahan Pajak, dan Keadilan Pajak Terhadap Kepatuhan Wajib Pajak UMKM ( Studi pada KPP Pratama Surabaya Karang Pilang. Hasil penelitian menunjukkan bahwa pengetahuan pajak dan kemudahan pajak berpengaruh positif terhadap kepatuhan wajib pajak UMKM. Sedangkan keadilan pajak berpengaruh negatif terhadap kepatuhan wajib pajak UMKM.

Penelitian yang dilakukan oleh Rosella dan Kurnia (2016) tentang Pengaruh Persepsi Atas PP Nomor 46 Tahun 2013 Terhadap Kepatuhan Wajib Pajak. Hasil penelitian menunjukkan bahwa persepsi keadilan pajak dan persepsi kemudahan pajak terkait PP Nomor 46 Tahun 2013 berpengaruh positif terhadap tingkat kepatuhan wajib pajak, sedangkan persepsi keserhanaan perpajakan terkait PP Nomor 46 tahun 2013 berpengaruh negatif terhadap tingkat kepatuhan wajib pajak.

Penelitian yang dilakukan Haryati dan Noviari (2016) tentang Analisis Peraturan Pemerintah Nomor 46 Terhadap Besarnya Pajak penghasilan. Penelitian ini menggunakan analisis deskriptif komparatif dengan hasil penelitian bahwa pada tahun 2014 masih banyak kesalahan dalam perhitungan peredaran bruto untuk setiap bulannya, sedangkan tahun 2015 jumlah pajak yang disetor sudah sesuai dengan Peraturan Pemerintah Nomor 46 tahun 2013. Dalam menbayarkan PPh terutangnya PT XYZ lebih diuntungkan dengan ketentuan umum UU Pajak penghasilan dibandingan dengan ketentuan PP Nomor 46, dan tahun 2015 mengalami kerugian fiskal dan dapat dikompensasikan pada tahun pajak berikutnya jika menggunakan PP Nomor 46 tahun 2013. 


\section{Pengembangan Hipotesis}

Pengetahuan pajak memberi pengaruh yang positif untuk kepatuhan wajib pajak. Salah satu penyebab berpengaruhnya pengetahuan pajak terhadap kepatuhan wajib pajak adalah adanya sumber informasi perpajakan yang didapat oleh setiap wajib pajak, misalnya informasi diperoleh dari petugas pajak, atau majalah pajak (Gardina dan Haryanto, 2006 dalam Permatasari, 2015).

Palil (2005) yang dikutip dari penelitian Rosella dan Kurnia, 2015 menemukan bahwa pengetahuan wajib pajak tentang perpajakan yang baik berpengaruh terhadap tax evation. Pengetahuan tentang peraturan pajak terkait PP Nomor 46 Tahun 2013 akan mempengaruhi sikap Wajib Pajak terhadap kewajiban pajak. Dari pernyataan diatas maka dapat dirumuskan hipotesis sebagai berikut :

\section{$\mathbf{H}_{1}$ = Pengetahuan pajak PP Nomor 46 Tahun 2013 berpengaruh positif terhadap tingkat kepatuhan wajib pajak}

Persepsi keadilan pajak terkait PP Nomor 46 Tahun 2013 merupakan penilaian Wajib pajak terhadap peraturan pemerintah yang berlaku pada tanggal 1 Juli 2013 yang mengharapkan adanya keadilan pajak pada setiap poin dalam peraturan tersebut. Widayati dan Nurlis (2010) menyetakan bahwa persepsi yang baik atas efektifitas sistem perpajakan mempunyai pengaruh yang tidak signifikan terhadap kemauan Wajib Pajak untuk membayar pajak. Sedangkan penelitian yang dilakukan oleh Bashori (2014) menyatakan persepsi keadilan Wajib Pajak atas PP Nomor 46 Tahun 2013 berpengaruh positif terhadap kepatuhan sukarela Wajib Pajak yang memiliki peredaran bruto tertentu pada KPP Pratama Surabaya Rungkut.

\section{$\mathbf{H}_{2}$ = Persepsi keadilan pajak terkait PP Nomor 46 Tahun 2013 berpengaruh positif terhadap tingkat kepatuhan wajib pajak}

Kebutuhan modal dan pengajuan kredit sering kali memaksa seseorang untuk memenuhi kewajiban pajaknya. Hal ini dikarenakan dalam pengajuan kredit sebagian besar Lembaga Keuangan penyedia kredit mensyaratkan adanya NPWP dalam proses pengajuan kredit. Oleh karena ada persyaratan tersebut maka calon kreditur harus mendaftarkan diri sebagai wajib pajak di KPP setempat, dengan mendaftarkan diri sebagai wajib pajak maka wajib pajak yang bersangkutan akan mendapat Nomor Pokok Wajib Pajak, dengan demikian maka wajib pajak diharapkan akan taat terhadap pajak.

Ningsih dan Rahayu (2015) melakukan penelitian tentang Pemanfaatan NPWP terhadap Kepatuhan Pajak menyatakan bahwa hasil penelitian tidak berpengaruh signifikan. Adanya NPWP tidak mempengaruhi kepatuhan wajib pajak dalam melaksankan kewajiban Pajak Penghasilannya.

\section{$\mathbf{H}_{3=}$ Kebutuhan Modal dan Kredit berpengaruh positif terhadap tingkat kepatuhan wajib pajak}

\section{METODE PENELITIAN}

\section{Populasi dan Sampel}

Populasi dalam penelitian ini meliputi seluruh UMKM yang ada di Kabupaten Rembang. Menurut catatan dari Kantor Dinas Perindustrian, Perdagangan, Koperasi dan UMKM tahun 2017, jumlah industri kecil dan 
menengah sebanyak 11.673 UMKM dengan jumlah sampel dalam penelitian ini sebanyak 200 UMKM. UMKM dipilih karena merupakan wajib pajak Orang Pribadi atau Badan yang menjadi subjek dalam pelaksanaan PP Nomor 46 Tahun 2013. Teknik pengambilan sampel dalam penelitian ini menggunakan purposive sampling, yaitu pengambilan sampel secara sengaja sesuai dengan persyaratan sampel yang diperlukan. Kriteria sampel pada penelitian ini yaitu :

1. UMKM di Kabupaten Rembang yang memiliki peredaran bruto tidak melebihi 4,8 Milyar Rupiah dalam satu tahun.

2. UMKM di Kabupaten Rembang yang memiliki NPWP.

3. UMKM di Kabupaten Rembang yang pernah mengajukan kredit kepada Lembaga Keuangan Perbankan.

\section{Teknik Pengumpulan Data}

Teknik pengumpulan data dalam penelitian ini menggunakan teknik survei dengan cara menyebarkan kuesioner secara langsung kepada manajer (pemilik) UKM yang memenuhi syarat pengambilan sampel. Kuesioner atau angket adalah teknik pengumpulan data dengan menyerahkan atau mengirimkan daftar pertanyaan ataupun pernyataan untuk diisi oleh responden.

\section{Uji Instrumen}

Dalam penelitian ini sebelum dilakukan survei, maka dilakukan terlebih dahulu pra survei. Dalam pra survei dilakukan pengujian instrumen, yang meliputi uji reliabilitas dan uji validitas. Pengujian reliabilitas dan validitas dalam penelitian ini menggunakan sampel sebesar 30 responden (Ghozali, 2011). Pengujian terhadap instrumen penelitian dimaksudkan untuk menguji apakah item-item pernyataan yang ada di dalam kuesioner valid dan reliabel atau tidak. Menurut Cooper dan Schindler (2006:318), data penelitian tidak akan berguna jika instrumen pengukuran

yang digunakan tidak mempunyai validitas dan reliabilitas yang tinggi dimana pengujian hipotesis sangat dipengaruhi oleh kualitas data.

\section{Teknik Analisis Data dan Hipotesis}

Teknik analisis data yang digunakan dalam penelitian ini adalah analisis regresi linier berganda dengan bantuan alat analisis Software SPSS for windows versi 21 dengan model sebagai berikut.

Keterangan :

$$
Y=a+b_{1} X_{1}+b_{2} X_{2}+b_{3} X_{3}+e
$$

$\mathrm{Y}=$ Kepatuhan, sebagai variabel dependen

$\mathrm{a}=$ Konstanta

$\mathrm{b}=$ Koefisien regresi

$\mathrm{X}_{1}=$ Pengetahuan Perpajakan, sebagai variabel independen

$\mathrm{X}_{2}=$ Persepsi Keadilan pajak, sebagai variabel independen

$\mathrm{X}_{3}=$ Kebutuhan Permodalan dan Kredit, sebagai variabel independen

$\mathrm{e}=$ standar error

Jurnal Akuntansi Indonesia

Vol. 8 No. 1 Januari 2019 


\section{HASIL PENELITIAN DAN PEMBAHASAN}

Uji instrumen dalam penelitian ini secara keseluruhan valid dan reliabel, meskipun ada beberapa item pernyataan yang tidak valid. Untuk item yang tidak valid tidak diikutkan pada penelitian selanjutnya. Dari hasil pengumpulan data sebesar 68\% (102) kuesioner yang bisa diolah sisanya 32\% (48) tidak kembali. Hal ini dikarenakan kebanyakan responden merasa takut mengisi kuesioner jika dikaitkan dengan pajak UMKM.

Berdasarkan hasil pengujian pada hipotesis pertama pada Tabel 1 maka hipotesis pertama pada penelitian ini terdukung dengan tanda koefisien positif. Hasil penelitian menunjukkan bahwa hipotesis 1 terdukung dan signifikan dimana nilai t hitung $(2,835)>t$ tabel $(1,9835)$, hal ini berarti bahwa pengetahuan pajak berpengaruh positif signifikan terhadap kepatuhan pajak.

Pengetahuan pajak secara signifikan berpengaruh terhadap kepatuhan wajib pajak UMKM dalam membayar pajak, semakin besar pengetahuan wajib pajak terhadap peraturan pajak PP 46 tahun 2013 maka wajib pajak UMKM semakin patuh dalam membayar pajak. Sementara untuk pengujian pada hipotesis 2 dan hipotesis 3 tidak terdukung dengan tingkat signifikan lebih dari 0,5\%. Hasil penelitian variabel keadilan pajak menunjukan thitung sebesar $-1,238<\mathrm{t}$ tabel sebesar 1,9835 sedangkan variabel kebutuhan permodalan dan kredit nilai t hitung sebesar -,159 < t tabel sebesar 1,9835. Dengan demikian kedua variabel tersebut tidak memiliki pengaruh terhadap kepatuhan wajib pajak UMKM PP 45 Tahun 2013.

\section{KESIMPULAN, KETERBATASAN DAN IMPLIKASI}

\section{Kesimpulan}

Dari hasil penelitian sampai sejauh ini dapat disimpulkan bahwa:

1. Pengetahuan perpajakan berpengaruh positif terhadap kepatuhan wajib pajak. Hal ini menunjukkan bahwa pengetahuan pajak dari WP sangat penting dalam meningkatkan kepatuhan wajib pajak dalam membayar pajak.

2. Keadilan pajak tidak berpengaruh terhadap kepatuhan wajib pajak. Ini menunjukkan bahwa keadilan pajak tidak dapat meningkatkan kepatuhan wajib pajak.

3. Kebutuhan modal dan kredit tidak berpengaruh terhadap kepatuhan wajib pajak. Ini artinya bahwa tingkat kredit wajib pajak tidak mampu meningkatkan kepatuhan wajib pajak.

\section{Keterbatasan}

Hasil pengumpulan data sebesar 68\% (102) kuesioner yang bisa diolah sisanya 32\% (48) tidak kembali. Hal ini dikarenakan kebanyakan responden merasa takut mengisi kuesioner jika dikaitkan dengan pajak UMKM.

\section{Saran}

Pada penelitian yang akan datang dapat mengganti item pernyataan yang tidak valid dan bisa meminimalisir kerusakan kuesioner (tidak diisi) dengan cara memandunya dan memberikan pengertian tentang pajak UMKM agar tidak salah persepsi dalam mengisi kuesioner karna kebanyakan pelaku UMKM beranggapan bahwa setelah mengisi kuesioner maka harus membayar pajak, sedangkan untuk kuesioner yang tidak kembali karena tidak bertemu secara langsung dengan UMKM dan dititipkan bisa dikonfirmasi dan didatangi lagi. 


\section{DAFTAR PUSTAKA}

Aditra, Al Hakim, dkk .2016. Implementasi Peraturan Pemerintah Nomor 46 Tahun 2013 Tentang Pajak Penghasilan Final Usaha Mikro Kecil Menegah (Kota Surabaya). Jurnal Perpajakan. Vol. 10. NO 1.2016.

Anggraeni, R.S. 2013. Pengaruh Persepsi Keadilan Pajak Terhadap Kepatuhan Formal Wajib Pajak Badan Pada Kantor Pelayanan Pajak Madya Surabaya. Skripsi. Fakultas Ekonomi dan Bisnis Universitas Airlangga. Surabaya.

Bashori, A.N. 2014. Pengaruh Persepsi Atas PP Nomor 46 Tahun 2013 Tehadap Kepatuhan Sukarela Wajib Pajak yang Memiliki Peredaran Brutp Tertentu pada Kantor Pelayana Pajak Pratama Surabaya Rungkut. Skripsi. Fakultas Ekonomi dan Bisnis Universitas Airlangga. Surabaya.

Brotodihardjo, R. S. 2003. Pengantar Ilmu Hukum Pajak. Bandung : Refika Aditama.

Chandler, R. C., dan J. C. Plano. 1988. The Public Administration Dictionary. John Wiley \& Sons.

Cooper, Donald R \& Pamela S.Schindler, 2006, "Bussines Research Methods", 9th edition. McGraw-Hill International Edition.

Disindakop dan UMKM Kabupaten Rembang, tahun 2014.

Endrianto, Wendy. 2015. Prinsip Keadilan Dalam Pajak Atas UMKM. Binus Business Review Vol. 6 No 2 Agustus 2015: 298-308.

Firdaus, N.A.2014. Pengaruh Pengetahuan Pajak, Kemudahan Pajak, dan Keadilan Pajak Terhadap kepatuhan Wajib Pajak UMKM (Studi pada KPP Pratama Surabaya Karang Pilang). Skripsi. Fakultas Ekonomi dan Bisnis Universitas Airlangga. Surabaya.

Ghozali, Imam . 2011. Aplikasi Analisis Multivariat dengan Program SPSS. Semarang : Badan Penerbit Universitas Diponegoro.

Haryati, Ayu Putu Mirah., dan Naniek Noviari. 2016. Analisis Penerapan Peraturan Pemerintah Nomor 46 Tahun 2013 Pada Besarnya Pajak Penghasilan. E-Jurnal Akuntansi Universitas Udayana Vol. 15.3. Juni 2016:24672493.

Maratis Suhartini, Atik, Ropika Yuta. 2014. Keterkaitan Lembaga Keuangan Mikro (LKM), Usaha Mikro Kecil (UMK) Serta Kemiskinan di Indonesia. Jurnal Ekonomi Kuantitatif Terapan (7) 2 Agustus 2014. Fakultas Ekonomi Universitas Udayana.

Ningsih, Heny Triastuti Kurnia dan Sri Rahayu. 2015. Pengaruh Kemanfaatan NPWP, Kualitas Pelayanan, dan Sanksi Perpajakan Terhadap Kepatuhan Wajib Pajak di KPP Pratama Medan Kota. Jurnal Syariah Accounting Fakultas Ekonomi Universitas Muhammadiyah Surakarta.

Nurazizah, Yayuk dkk. 2011. OASIS Pemotongan/Pemungutan/PPh. Jakarta: Andi

Peraturan Pemerintah Republik Indonesia Nomor 46 Tahun 2013 Pajak Penghasilan atas Penghasilan dari Usaha yang Diterima atau Diperoleh Wajib Pajak yang Memiliki Peredaran Bruto Tretentu. 12 Juni 2013. Lembaran Negara Republik Indonesia Tahun 2013 Tahun 2013 Nomor 106. Jakarta.

Rosella, Vina dan Kurnia. 2015. “Pengaruh Persepsi Atas PP Nomor 46 Tahun 2013 Terhadap Kepatuhan Wajib Pajak. Jurnal Ilmu \& Riset Akuntansi, Vol. 4 No 9. 
Widayati dan Nurlis. 2010. Faktor-Faktor yang Mempengaruhi Kemauan Untuk Membayar Pajak Wajib Pajak Orang PribadiYang Melakukan Pekerjaan Bebas (Studi Kasus pada KPP Pratama GambirTiga). Simponsium Nasional Akuntansi XIII Purwokerto.

www.liputan6.com. Diakses melalui media elektronik pada tanggal 01 juni 2017. Pukul 11:03 WIB. Zain, M. 2004. Manajemen Perpajakan.Jakarta: PT Salemba Empat. 


\section{LAMPIRAN}

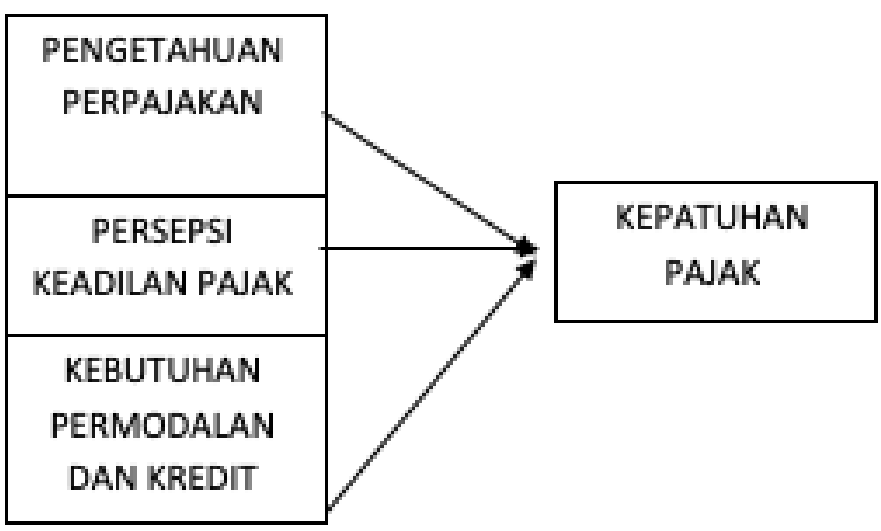

Gambar 1. Kerangka Pemikiran Penelitian

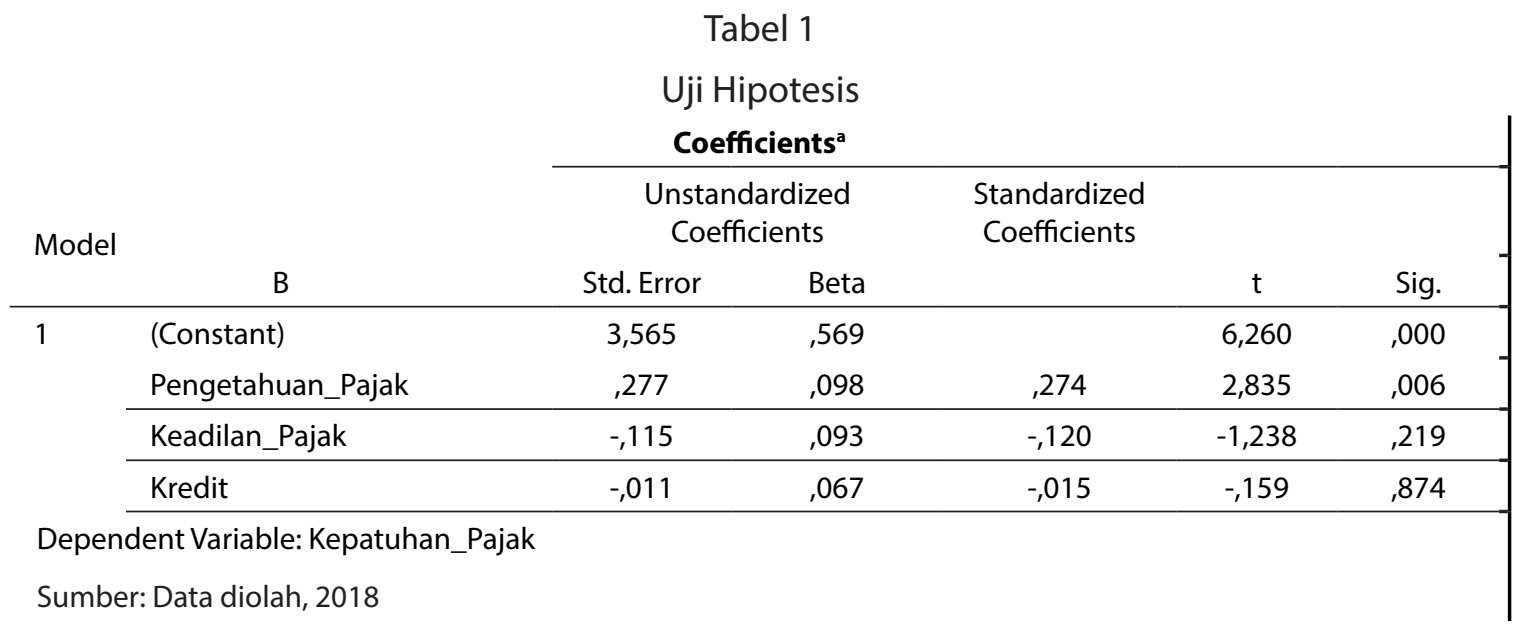

